\title{
Retraction: colon and rectal surgery for cancer without mechanical bowel preparation: one-center randomized prospective trial
}

Stefano Scabini", Edoardo Rimini, Emanuele Romairone, Renato Scordamaglia, Giampiero Damiani, Davide Pertile and Valter Ferrando

Retraction

The authors have retracted this article [1] because it contains large portions of text that have been duplicated from another article previously published in Annals of Surgery [2]. The authors apologise to the Editors and readers as well as the authors of the original article.

Received: 18 September 2012 Accepted: 18 September 2012

Published: 20 September 2012

\section{References}

1. Scabini S, Rimini E, Romairone E, Scordamaglia R, Damiani G, Pertile D,

Ferrando V: Colon and rectal surgery for cancer without mechanical bowel preparation. One Center Randomized Prospective Trial 2010, 8:35.

2. Zmora O, Mahajna A, Bar-Zakai B, Rosin D, Hershko D, Shabtai M, Krausz M, Ayalon A: Colon and Rectal Surgery Without Mechanical Bowel

Preparation. A Randomized Prospective Trial 2003, 237(3):363-367.

\section{doi:10.1186/1477-7819-10-196}

Cite this article as: Scabini et al: Retraction: colon and rectal surgery for cancer without mechanical bowel preparation: one-center randomized prospective trial. World Journal of Surgical Oncology 2012 10:196.

* Correspondence: stefanoscabini@libero.it

Unit of Surgical Oncology, Department of Emato-Oncology, San Martino Hospital, Genoa, Italy

Submit your next manuscript to BioMed Central and take full advantage of:

- Convenient online submission

- Thorough peer review

- No space constraints or color figure charges

- Immediate publication on acceptance

- Inclusion in PubMed, CAS, Scopus and Google Scholar

- Research which is freely available for redistribution

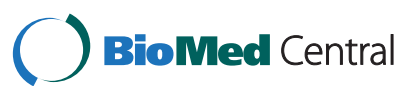

(C) 2012 Scabini et al.; licensee BioMed Central Ltd. This is an Open Access article distributed under the terms of the Creative Commons Attribution License (http://creativecommons.org/licenses/by/2.0), which permits unrestricted use, distribution, and reproduction in any medium, provided the original work is properly cited. 